April 2013

\title{
A Qualitative Study Using Community Cultural Wealth to Understand the Educational Experiences of Latino College Students
}

\author{
Nora A. Luna \\ University of Nevada - Reno, noraluna5@hotmail.com \\ Magdalena Martinez Ph.D \\ Nevada System of Higher Education, magdalena_martinez@nshe.nevada.edu
}

Follow this and additional works at: https://digitalscholarship.unlv.edu/jpme

\begin{abstract}
Repository Citation
Luna, Nora A. and Martinez, Magdalena Ph.D (2013) "A Qualitative Study Using Community Cultural Wealth to Understand the Educational Experiences of Latino College Students," Journal of Praxis in Multicultural Education: Vol. 7: No. 1, Article 2.
\end{abstract}

DOI: 10.9741/2161-2978.1045

Available at: https://digitalscholarship.unlv.edu/jpme/vol7/iss1/2

This Article is protected by copyright and/or related rights. It has been brought to you by Digital Scholarship@UNLV with permission from the rights-holder(s). You are free to use this Article in any way that is permitted by the copyright and related rights legislation that applies to your use. For other uses you need to obtain permission from the rights-holder(s) directly, unless additional rights are indicated by a Creative Commons license in the record and/ or on the work itself.

This Article has been accepted for inclusion in Journal of Praxis in Multicultural Education by an authorized administrator of Digital Scholarship@UNLV. For more information, please contact digitalscholarship@unlv.edu. 


\section{Introduction}

The importance of college attainment in the U.S. has received much attention since President Obama's call to be the global leader in postsecondary completion. College completion rates are low across all segments and populations and among Latinos, who represent the largest and youngest population of color, the completion rates are staggering. Many suggest that the country's ability to be the global leader largely depends on the ability to educate and graduate Latino youth. This is certainly the case in many states such as California, Texas, Florida, Arizona, and Nevada. Latino students make up the largest population of color.

Historically education research placed the burden of education attainment on students and parents. One main argument stated that education was not valued or encouraged. However, the research as well as practitioner communities realize this perspective yields limited results and incorrectly casts the Latino community. In fact, recent research has begun to focus on successful students and elements that help them achieve academically.

This study provides a literature review of reasons for Latino students' low academic achievement and factors that support school success. In addition, the authors introduce the Community Cultural Wealth Model (Yosso, 2006) to help interpret and understand findings from the study. The article presents data on the knowledge, skills, abilities and networks or community cultural wealth, that Latino students used to overcome obstacles, navigate educational settings and excel academically. Finally, recommendations for research and practice are presented.

Literature Review

Latino students continue to be underrepresented in postsecondary institutions (León, 2003). Scholars and researchers have significantly contributed to the understanding of the reasons why Latinos are underrepresented in colleges and universities. Among their findings, key factors that Latino youth must contend with include academic preparedness, access to college-bound curriculum, financial aid, access to college information, mentoring and advisement, and family commitments (León, 2003; Llagas \& Snyer, 2003; Olivas, 1986; StantonSalazar, \& Dornbusch, 1995; Suárez-Orozco \& Páez, 2002). Latino students, who are able to make it through the educational pipeline to college, often face additional challenges. A report by the Pew Hispanic Center found that Latino youth are at a disadvantage when compared to other equally prepared students for completing a bachelor's degree. The report identified two main reasons: Latinos enroll in less selective institutions when compared to white peers and "[Latinos] have different experiences than white students even when they enroll on the same campus" (Fry, 2002, p. vi). The report states that Latino students have "greater financial responsibility for family members, and [are more likely to be] living 
with family while in college rather than in campus housing" (p. 16). Not mentioned in the report, however, is the mounting research on racially hostile college climates, unwelcoming environments and the potential influence on student experiences and persistence decisions (Clements, 2000; Hurtado, Milem, Clayton-Pedersen, \& Allen, 1998; Rhoads, 1999; Solórzano, 1998). Other reports on the plight of Latino education, based on deficit assumptions, assert that home and family culture often deters academic success (e.g., language use, family and community commitments, strong ethnic identity). However, a new line of research looks at Latino students who, despite economic, political, and structural challenges, are high academic achievers. A look at these studies offer new insights into the role of Latino culture on educational experiences and the ways students develop culturally-based survival strategies (Delgado Bernal, 2002; Gonzalez, Moll, Amanti, 2005; Hurtado, 2003; Orelleana, 2003; Yosso, 2006).

In postsecondary persistence literature, theoretical models assume student assimilation to campus and its academic and social spheres are important prerequisites for persistence; also known as integrationist models because they assume students must integrate into college to be successful (Tinto, 1987, 1993, Bean, 1980, 1983). Other theoretical frameworks on Latino college experiences bring to the forefront material, structural and cultural circumstances that students must contend with in order to achieve their postsecondary goals. Indeed, student persistence is perhaps one of the most studied areas in higher education. For at least three decades, practitioners, researchers and policymakers have sought to understand what factors contribute to the likelihood of students' decision to depart from or continue in their college pursuits (Astin, 1972, 1982; Pascarella \& Terenzini, 1979, 1980; Spady, 1970; St. John, Cabrera, Nora \& Asker, 2002). However, researchers lament the inability of persistence models to account for the complex reasons why students leave college. Even after academic preparedness (before and during college) is controlled for, researchers find that students depart and the majority of students depart for non-academic reasons.

Theoretical Framework

This study uses the Community Cultural Wealth Model (Yosso, 2006). Community cultural wealth shifts the view from a deficit perspective to the assets that communities of color acquire. In contrast, the current educational policies stem from deeply embedded assimilationist practices that continue to place Latino students at an educational disadvantage and view students and their families as intellectually and culturally inferior. Community cultural wealth includes an array of cultural knowledge, skills, abilities and contacts of socially marginalized groups that usually go unrecognized, acknowledged or celebrated (Yosso, 2006) by Whitestream schools (Urrieta, 2009). This approach to understanding Latino student success and barriers brings to the forefront structural barriers and 
sociopolitical histories and contexts. The results of these barriers and contexts include unequal funding for schools, neighborhood and school racial segregation, overcrowded schools, poorly maintained facilities, less experienced and undercredentialed teachers and minimal resources. Subsequently, students have less access to academic guidance counselors, academically rigorous enrichment programs and courses resulting in "tracking" Latino students into remedial or vocational courses. A lack of adequate bilingual and multicultural education, inappropriate high-stakes assessments and discriminatory practices further place students at a disadvantage.

The Community Cultural Wealth Model asserts that various forms of capital fostered through cultural wealth, such as aspirational, familial, social and navigational, are used by communities of color to survive and resist oppression and discrimination (Yosso, 2006). Community cultural wealth is used by Latinos in order to survive the institutional neglect of the U.S. public school system that has historically failed them. These categories are not static or mutually exclusive, rather they are dynamic processes that build on one another as part of a community of cultural wealth. The Community Cultural Wealth Model begins with the perspective that communities of color are places with multiple strengths, cultural assets and cultural wealth. This perspective serves as a tool to move toward social and racial justice and demonstrates the need to restructure not only education systems, but other social institutions around the community's knowledge, skills, abilities and networks. For this paper the authors focus on four forms of community cultural wealth: 1) aspirational or "the ability to maintain hopes and dreams for the future even in the face of barriers" (p. 41); 2) familial or "cultural knowledge nurtured among familia (kin) that carry a sense of community history, memory and cultural intuition" (p. 48); 3) social or "networks of people and community resources" (p. 45); and 4) navigational or "skills for maneuvering through social institutions not created with Latinos in mind" (p. 44). Throughout this paper, the authors highlight how a group of Latino college students used these forms of capital and how they mediated or mitigated their educational challenges.

\section{Method \& Analysis}

This qualitative study was part of a larger study that examined educational school dropout prevention programs and the educational experiences of Latino students in high schools and universities. The data were collected between the fall of 2008 and spring of 2009. The authors conducted focus groups. For this article, a sample of fifteen academically successful Latino students participated in two focus groups. "Successful" in this study is defined as students who graduated from high school and were enrolled full-time in a four-year institution. 
A purposeful sample of nine participants attended the first focus group and eight participants attended a second focus group. To recruit participants, the lead author used personal contacts at a local university to invite participants who identified themselves as Latino, Hispanic or Chicano and were enrolled full-time. A large public university located in a fast-growing southwest metropolitan city with a population of 1.5 million was selected (U.S. Census Bureau, Fact Finder, 2005-2007). The main author negotiated entry into the campus through university and personal contacts. Participants were asked to select a fictitious name to ensure anonymity. Names used in this article are pseudonyms.

A focus group questionnaire and protocol were used to ensure consistency. Approximately ten probing questions were asked during the focus groups and each focus group was nearly two hours in duration. Based on relevant literature regarding Latino students, the focus group involved open-ended questions designed to elicit the participants' perceptions about factors that contributed to their academic success (Arellano \& Padilla, 1996; Gandara, 1995). The focus group discussions were audio-taped then transcribed verbatim.

Data analysis consisted of categorizing the participants' responses according to the Community Cultural Wealth Model (Yosso, 2006). According to Spradley (1980), an "analysis is a search for patterns" (p. 85). In order to understand the cultural patterns that supported Latino students' achievement content, domain and taxonomic analyses were conducted. The content analysis was done by inductively searching through the transcription for references to the themes and concepts identified in the literature (Berg, 2001). For the purpose of the content analysis, most comments were assigned only to one code, however in several instances comments were assigned to more than one code. The domain analysis was done by searching for patterns of the contributing factors to educational success, obstacles to educational success and recommendations from participants to improve the high school graduation rate (Spradley, 1980). To develop the domains, quotes were underlined from the transcription that referred to one of the three items listed above (factors contributing to academic success, obstacles or recommendations). On the side column, the domain was noted. The taxonomic analysis was developed by representing in a figure the "relationship among all the included terms in a domain" (Spradley, 1980, p. 113).

\section{Findings}

Participants in the study frequently discussed the use of culturally or ethnically based knowledge, skills, abilities and contacts to survive macro and micro forms of aggression in school and excel academically. The findings are presented within a framework of the following community cultural capital: aspirational, familial, social and navigational. 


\section{Aspirational Capital}

Aspirational capital refers to the ability to hold on to hope and dreams despite inequality and often without the means to make those dreams come true (Yosso, 2006). Aspirations are developed through familial and social contexts. Participants repeatedly discussed the high aspirations their parents had for them. Although none of the participants had parents who had gone to college, they all shared stories from their parents about the importance of education, going to college and doing "something meaningful in life." All of the participants reported having academic goals that included attending college. "I just knew I wanted to do something meaningful with my life and the best way would be pursuing higher education," said Mariana. Linda said, "I wanted to be the first in my family to have a degree because nobody in my family has a degree." Most of the participants had grown up in poverty and were first generation college students, although several participants' parents were able to either pay for their entire college tuition or help substantially. They had lived through adverse living conditions yet continued to have high aspirations. Their statements provided insights into possible motivators for their goals. For example, Josefina had witnessed the struggles of her family,

My dad only went up to sixth grade. My mom, I think she finished middle school and she started, like a career in Mexico, but it was for only for one year. My dad was forced to leave school because he was in a big family. There was 12 kids so each one, like had to work to support the family. And my mom had to leave because my grandpa didn't really think that women should...have an education. Anyway, so I grew up like with their stories and my dad would always say that he was really smart and that the only reason my dad didn't go to school... was because of like him having to work. So I knew ... that I wanted to finish high school so I would set goals for myself... I'm not gonna do that...so that I could graduate from high school.

Thomas talked about increasing his aspirations after experiencing some success in college. He also extended his aspirations to want to make changes for others. Thomas, who is a graduate student said, "I did really well my senior year and I was really amazed about what I could do in school so I figured... why not, why not? I came this far why not keep going...I just was really fascinated about what else I could learn about myself...I wanted to see a change in my environment."

\section{Familial Capital}

Familial capital is "cultural knowledge nurtured among familia (kin) that carry a sense of community history, memory and cultural intuition" (Yosso, 2006, p. 48). Mothers, fathers, sisters, brothers, grandmothers and other extended family 
were all mentioned by participants as strong transmitters of educational aspirations and moral lessons, as well as direct providers of support in school and in learning life lessons. Each participant reported having support from his or her family. Their family support included having high expectations, encouragement in the forms of advice, stories and hard work. Mariana explained that her parents helped her by coming to the United States, "well, just the fact that we are here, that my family and I are here because they cared about giving us a better future. They've always been supportive, but it was our choice. Out of four siblings, I'm the only one that's going to college right now." Linda, who was majoring in psychology said, " my parents, they were always pushy about school, since I lost track in high school they wanted me to get back on track and go to school...family members, aunts, they would always tell me, when are you going to sign up for school. We're waiting for you to go to school [college]."

Alfredo, a student active in several Latino campus organizations stated, "One of the reasons I decided to come to college was seeing my mother 'cause she does clean houses and I guess I didn't want to be in the labor force just because it is a very tiring thing and it does take a toll on your body." He said his mother, who started working since the age of eight, was "always telling me you have to go to college. It is a better life. And another important reason that I did come to college was my brother, he did not graduate." Alfredo said his brother was criticized by society for not graduating from high school, yet he was not given the same opportunities as others. Alfredo felt that his brother not graduating was a big part of his decision to attend a university. He explained why,

My mother was in an abusive relationship and my brother then became responsible for me and my younger brother when my mother decided to leave my father. He would cook for us, take us to school, all that stuff. Because of the responsibility he faced, knowing that we were poor, knowing that many of the things that he wished he could change were out of his control, knowing that his dream of being an immigration lawyer to help people like my mother who was deported twice was nearly impossible because the horrible education in [my city]. Because we were poor [it] was just a dream. He ended up joining a gang...I felt obligated from a very young age maybe in the 5th grade, to help change destinies like my brothers because it was filled with so much pain. And because there was so much pain present I feel like I felt that pain and continue to feel it. It was this pain that inspired me, motivated me, angered me, frustrated me, made me cry, made me feel so many things I still can't explain. To have an education because my mother once said that with an education I won't have to bust my ass off, be taken advantage of, be humiliated, be working in horrible conditions. To come home and pay the rent and light bill while there is no food in the refrigerator. My brother had 
to understand this at around age five...because he wasn't able to make his dream a reality, because he faced so much pain, because now he struggles to feed his children. I was inspired to go to college. Because when he joined a gang, the moment I found out, I knew he would be seen as a delinquent, as a criminal. And I knew the people who judged him are the same ones who forced him into joining a gang by denying his human right for a quality living. I want to change things for many like him.

Alder, another participant said that for him it wasn't a choice, "my parents preordained me to go to the university level and I never really gave it much thought." He also says his freshman year of high school, his sister was a freshman at a selective university. He felt he had to go to college. He mentioned being afraid to go away to college and decided to stay in his hometown to attend college. He shared,

Well, my mom and my pops they didn't get very far in school. Just like middle school pretty much and then my pa was always telling me stories. I work so hard and I don't want you to work this hard and education is very important it's a luxury not many people can afford it. I break my back everyday to get you through school and you gotta help yourself out too, getting a scholarship. I'm gonna help you of course, but I just don't want to see you suffer like I did. He used to always, always say that. That stuck with me and then my sisters. They were really into school. Not that I wasn't, but you know it helped just being in that environment so me and my sisters had study groups and all that and very close family.

Merlinda described how different family members were involved in her academic goals and aspirations,

I would say that my experience is very similar to everyone else's. My father and my older sister, in particular, really pushed me to take advantage of the [state merit-based scholarship]. Although both my older sister and my dad didn't really know about the nature of getting an education... you couldn't possibly involve them on the application process and letters of recommendation, those little things that I had to find out on my own. Whereas my mother, when my interests were strongly driven towards graduate school and a Ph.D. which up until this last year I didn't think I was qualified for, but my mom wanted me to go into jobs that she felt were safe. So she wanted me to be become...a pharmacist. I think she has done research on it actually or just being a grade school teacher or something that are more like on a traditional gender expected jobs, especially nursing. I think my mom wanted me to do what was expected. My dad and my sister really pushed me to go the academic route. 


\section{Social Capital}

Participants also credited networks of people, contacts and community resources or social capital with helping them in high school and college. For example, one participant described a time when she was in line to sign up for classes and her friend said, "Come over to this line. This is for classes if you want to go to college." Another participant mentioned going to a magnet school where everyone was talking about going to college which she also credits as an influence toward college attendance. Moreover, participants mentioned wanting to help people of color as a reason they continued their education. Alfredo said, “... another [reason for attending college] is not seeing people of color in, I guess, high places, such as education and political positions and those who sometimes weren't really helpful to people of color with struggles that they've had. And that's one of the reasons I wanted to go to college to get an education. " Their statements provided insights into how they use their social contacts and networks to excel in educational settings. Furthermore, some participants were critical of the current system that seemed to push students into the military. For example, Josefina described how a teacher's attitude pushing her toward the military and the contacts she made at a leadership conference pushed her to attend college,

For a long time before I started in my freshman year in high school I wanted to go to the military because I wanted to somehow like pay for my education ... I think it was the reactions I received from my teachers that pushed me in the other way because one of my teachers was like, yeah you'll be great. You should go into the military and it was kinda weird how everyone was so enthusiastic about me going into the military. But no one had ever really helped me as far as like going to college... I also attended a conference my sophomore year in high school. I attended two conferences. One was a Latino youth conference ... which was in between my sophomore and junior year. That really helped me, like, focus as far as how to go through the process and because I met so many people that were already in college.

The social contacts with other Latinos seemed to be of particular importance to students in the study. They talked about seeking out other Latino students and organizations for support. Josefina said,

When I went to high school, the first thing I looked for was like clubs to join...so I wouldn't feel like alone in high school... I joined [a student ethnic organization] when I was in high school. And then after going through the Latino youth conference, I was also in the alumni organization with them so it was just like constantly looking for support and mostly it was with Latino people. 
Similarly, Alder talked about "sticking with your people,"

Well, my high school was kinda rough. So part of my culture is just like finding your people. Sticking with your people, and hoping that they'll get your back. I did that... it worked for me for a while, but not all the time. It kinda helped me survive. It was kinda a survival thing. I don't know it was just a really bad school, so that pretty much, not the violence thing, just sticking together and finding your own people. Finding a common ground with somebody not being totally outcast... As a culture, I think we're just taught not to do things by ourselves. Have someone do it with you. Don't go at it alone.

Historically Latino students and families utilize their social capital to maneuver social institutions, such as higher education, then in turn provide the information they learned from navigating the system back to their social networks (Yosso, 2006). The students in the study discussed and lived the importance of their social networks. For example, three students who were cousins had graduated from a rural high school about two hours from the metropolitan city where they were attending college. They shared an apartment, a car and a computer, but more importantly they provided emotional support to each other while away from home.

\section{Navigational Capital}

Participants described "skills for maneuvering through social institutions not created with Latinos in mind" (Yosso, 2006, p. 44). Navigating the college process requires skills. They credited their social networks in helping them navigate and understand the school systems, the process to enroll in college, applying for financial aid and finding support on campus. "In high school I was not taught what you need to be college-bound as far as what you need to do, letters of recommendation, what courses you need to take, signatures you might need and how to get them or where to get finances," said Alfredo, yet he and others found a way to persist. "I started becoming involved in the community, in school when I was a junior in high school and through that I met a lot of mentors and leaders in the community that helped me through the process of going to college," said another participant.

The college application process was not the only area where navigation capital was utilized. One participant discussed attending a high school where "anything Latino was not welcome." She said the Latino student organization had fallen apart and when she went to inquire about reorganizing it, "the school told us that there would be like no point...you couldn't find a teacher ... and that you know there was really no point in continuing like the organization." She and other 
students did find a teacher to be the advisor yet they continued to face obstacles from the school personnel. The students involved community people and eventually contacted a Latino school board member, and subsequently, students were able to form their organization. Alfredo also mentioned having problems at his high school trying to organize a Latino club. He and other students found a solution by changing the name of the club, excluding "Latino" from the title.

\section{Obstacles}

Participants described the obstacles they overcame to successfully graduate from high school and attend college. Latino college students used community cultural wealth as a tool to move toward social justice through educational achievement. Students in the study described the inequities that people experience as a result of membership in specific groups, such as being tracked non-college. Alfredo said, "Whenever I ask counselors or teachers, I guess, for advice of how to get into college, they never actually told me what steps I had to take. It was just, 'well you need to take more advanced classes' and the classes I was put into were actually not advanced classes." Adrian stated no one at school had ever talked to him about college until one day his senior year when a university recruiter conducted a session at his school. Mary shared her story,

I still kind of like get angry about it. It was in the eighth grade I was in this science. It was earth science and I finished the class with an " $A$ " and we were going up to get all our papers signed and you know she [the teacher] was recommending classes to everybody. She recommended earth science for me for high school and all my friends got the next one up, biology. Well, why am I not going to biology and she said "Oh, I just don't think you'll do good, earth science is good though, it's a good class." But well, why can't I just get biology? She says, "no, just work with it for a while and see what you think." I went back to my friends. They were like well maybe you're just not good enough. Well I don't know, they were saying all this stuff...I got really mad and got really sad and said forget it. I ended up liking my science teacher even though it was really easy.

Alder described the obstacle of being tracked in non-college and toward the military. He shared the following experience,

She [school counselor] didn't tell me...things about university level. She just automatically talked about the Army and it's like "I think you'll do pretty good, you're a strong looking kid"...My cousin, who is at [the university] one of his teachers told him to join the Army. She was telling him all these things and you know, be patriotic and this and that. My cousin told me that, so I went up and I had a talk with her [teacher] and 
she changed her mind. [My cousin] would say "I shouldn't be doing that. I should be geared towards a university." They have it in their mindset that Army, you know, is just the next best thing... The military recruiters are there more than university recruiters...I think that is a fucking crime, to be honest.

Merlinda further elaborated,

I have gone through grade school my entire time here in [this city] and I knew very little of even [this university], you know...I think it really says something that I have grown up here, I didn't even know about our local university... My brother grew up with a solid group of friends and he was the only one that did not enlist in the military. And they [military recruiters] were there, I remember, I went to [high school] and they were there. I remember they had tanks in the courtyard. They were actively recruiting all the time so and I don't recall at all there being a college resource fair.

A major obstacle mentioned by every participant was the lack of financial means to attend college. Eddie stated, "I graduated with 3.0...trying to get finances was an obstacle. I think my [obstacles] were finances and not knowing where to look for scholarships...The only reason I ended up going to [the university], I did because of the [state merit-based scholarship] and it automatically happened." Monica said her biggest obstacle had been balancing full-time work and school due to finances. The recent economic crisis also impacted otherwise financially stable Latino students. For example, one participant shared, "my parents have businesses that are making like 25 percent of what they made last year, so now this year I am looking for a job. I need to find ways to pay for my education...I always had money because that wasn't a problem until now, now it's like I have to find scholarships; I have to find a job and make sure I have enough to continue." Unfortunately, due to work and school, participants did not always have the time to search for scholarships and complete financial aide and scholarship applications. Adrian explained, "I have actually had to give more money to my family than they have been able to support me through college...I haven't always had time to fill out scholarships and I didn't have a lot of people that showed me how to do that."

Other obstacles mentioned by participants included lack of knowledge about college, being credit deficient, unfamiliar with the U.S. education system and language. Christy described her lack of knowledge,

I really didn't understand how transferring credits really worked and so normally that process. I started out doing business just because... and then when I transferred over to [the university] I did psychology. And so even 
just wondering just what parts would transfer. So I lost some credits due to that. I had to start all over again and then not really knowing a lot about scholarships.

Alder talked about having to go to "early bird and late bird" in order to catch up because he wasn't doing "very well" in high school. Another participant said language was an obstacle, "I'm just learning [English] because I have three years here in the United States, so I try to learn fast."

\section{Discussion}

The current study examined how a group of high-achieving Latino college students used a variety of community cultural wealth knowledge, skills, abilities and networks to attain educational success. Several important findings merit discussion. One key finding in the study is that Latino parents largely shape their children's academic aspirations. Parental support included high educational aspirations and encouragement to pursue those goals. In fact, many students in the study reported not being aware they could do college-level work, but it was the encouragement they received from their families that facilitated high educational aspirations and achievement. Although most parents could not contribute to the cost of college or help their children navigate the college application process they provided support in other ways, such as words of inspiration and encouragement. Familial and aspirational capital were crucial elements cited by Latino college students in their decision to pursue higher education. Without the familial support, it is possible that some of the participants might not have pursued higher education. The study findings suggest that Latino students bring to school knowledge, skills, abilities and networks that usually go unrecognized and undervalued in educational settings. One important aspect that merits further research and exploration is Latino parental involvement in instilling educational values and teacher/school recognition of Latino parental involvement. Traditional school rhetoric continues to call for "parental involvement" and often this rhetoric does not account the ways that Latino parents are involved in educating their children and assumes that Latino parents do not encourage their children to pursue high academic goals (Lopez \& Vazquez, 2006). Parental involvement needs to be re-defined to include the type of support Latino parents provide that motivates and encourages higher education. Mainstream schools seem to underestimate the assets that Latino families pass along to their children. These assets can be the basis for understanding the cultural systems of Latino children and can become valuable tools in the classroom. For example, some practices common in Latino households, such as not allowing children to leave home for college (Rodriguez, Guido-DiBrito, Torres \& Talbot, 2000) should not be confused with the notion that parents do not value education. From a community cultural wealth 
perspective family cohesiveness is as important as education. Teachers and counselors can explain differences among institutions to parents and withhold judgment.

Public schools are traditionally structured to help "disadvantaged" students who "lack" the social and cultural capital required for educational success and social mobility. The data from this study sheds light on how Latino students use social and navigational capital to navigate educational settings. Students in the study reported the use of social capital in a variety of ways that supported their educational achievements. For example, students reported learning about what classes they needed to take in high school to improve their opportunities for college, where and how to access financial aid and consciously seeking "your own people" for support. Relationships were very important to the success of the students. Relationships constitute social capital when they enable the achievement of goals that otherwise would not have been possible individually. In this regard, educational achievement is not an individual attribute, rather the result of a collective process of commitments among and between individuals who are embedded in a supportive aspirational network (Valenzuela, 1999). In this study social capital fostered trust, norms and expectations among youth who came to share a common goal of academic success by doing homework together, sharing a computer or belonging to a study group.

Another finding was that despite low teacher expectations students held high aspirations. Many participants were not aware of what was needed to go to college. One major obstacle to college attendance among the study participants was "never being told I could go to college." Some of the study participants were not high academic achievers in high school, yet they succeeded in higher education. Lack of success in high school does not necessarily translate to failure in college. Gandara \& Contreras suggest that 'teachers' beliefs about children's abilities can either enhance or reduce school performance, and teachers' assessments of student potential begin at a very early age" $(2009$, p.103). In addition, cultural differences between teachers and students have been shown to contribute to low expectations of the students' academic abilities. An important factor that contributes to low expectations is the fact that Latinos are more likely to be placed in lower performing groups upon entering school. Students will come to see themselves as not as smart as those in the higher reading groups setting them on a certain path for the rest of their school years (Gandara \& Contreras, 2009).

A limitation to this study is sample size. In the future, a larger number of students' perspective can be examined, as well as including middle and high school students. This study supports the Community Cultural Wealth Model as a valuable lens to address the educational issues confronting Latino students. In addition, this study points to a gap in parent education and college access 
programs aimed at middle school families. Future research is needed to examine community cultural wealth in communities of color and how the various forms of capital can be supported in order to increase student achievement. In addition, the community cultural wealth that Latino parents provide should to be further explored and understood. The cultural deficit model permeates society today perpetuates educational inequalities. This study is consistent with other literature which finds that Latino parents hold high educational expectations for their children (Arellano and Padilla, 1996; Cabrera \& Padilla, 2004; Sanchez, Reyes \& Singh, 2006; Zalaquett, 2005).

\section{Conclusion and Recommendations}

Latino students bring with them a wealth of knowledge, skills and talents that traditionally are not valued in educational settings. This study demonstrates that Latino students value education and have high educational aspirations. Further, these aspirations are shaped by their lived experiences, family and school interactions. By gaining an in-depth understanding of how Latino students are shaped by their community cultural wealth educators, policymakers, and administrators can better serve and help student achieve their educational goals. To improve educational attainment for Latino students, the following recommendations can begin to address the many educational inequities.

School personnel should communicate and establish high educational expectations for all students and provide specific information and guidelines to postsecondary options. Parental involvement should be redefined to include the various forms Latino parents are involved in their children's education. Traditional expectations include volunteering in the classroom and participating in the Parent Teacher Association. While these are important activities, Latino parents should not be judged as apathetic or as not valuing education if they cannot volunteer in this manner. Other parent involvement can include storytelling, advising and motivating youth to continue with school. Understating students' culture and honoring their stories and histories provides validation to students and their families. Cohesiveness is a value that characterizes many Latino families. For example, students can be asked to document their bicultural history and experiences through writing assignments.

Gonzalez, Moll, and Amanti (2005) identify ways that immigrant children and children of immigrant parents use their home-based knowledge to navigate and succeed in everyday contexts, yet this knowledge is seldom incorporated into teaching and learning settings. Bicultural and bilingual skills should be framed as assets and can enhance the teaching and learning setting for all students. Schools can support language assets by recognizing, valuing and respecting the student's home language. The use of code-switching between English and Spanish in the classroom is often viewed as a negative, but can be viewed as a positive tool to 
increase comprehension. School personnel should avoid judging Latino students' language as slang and recognize the unique evolution of the Mexican-Spanish which includes many words originating from Nahuatl, the language of the Aztecs and still today, the most spoken indigenous language on the North American continent.

Schools, in partnership with colleges and universities, can identify and communicate clear pathways to careers and postsecondary options. Parents and students can benefit from understanding the types of careers and the types of high school courses necessary to achieve their career and college goals. Equally important is financial literacy. Students and parents who are the first to attend college often do not have complete and accurate information on how to save and pay for college.

Once in college, postsecondary institutions can create welcoming climates where students integrate into campus and feel a sense of belonging. Recent research confirms the importance of student organizations, in particular ethnic student groups, to the college experience of underrepresented populations (Hurtado, Milem, Clayton-Pedersen, \& Allen, 1998). As evidenced in this study, participants often found student ethnic organizations as critical to their ability to navigate campus and academic settings.

The purpose of this study was to provide insights into the community cultural wealth used by Latino students as they move toward greater academic achievement. The following forms of community cultural wealth played an important role in each student's academic success: aspirational, familial, social and navigational capital. It is the hope of the authors that these findings will provide insight into how school and college personnel can acknowledge, value and respect Latino students strengths in order to encourage Latino educational success. 


\section{References}

American Council on Education. (2008). Generational gains in postsecondary education appear to have stalled, new ACE report finds. Retrieved December 1, 2008, from

http://www.acenet.edu/AM/Template.cfm?TEMPLATE=\%2FCM\%2FCo ntentDisplay.cfm\&CONTENTID=29515\&Section=Press_Release2

Arellano, A.R., \& Padilla, A.M. (1996). Academic invulnerability among a select group of Latino university students. Hispanic Journal of Behavioral Sciences, 18, 485-507.

Astin, A. W. (1972). College dropouts: A national profile. Washington, DC: Office of Research American Council on Education.

Astin, A. W. (1982). Minorities in American higher education (1st ed.). San Francisco: Jossey-Bass.

Bean, J. P. (1980). The synthesis of a causal model of student attrition. Research in Higher Education, 12, 155-187.

Bean, J. P. (1983). The application of a model of turnover in work organizations to the student attrition process. Review of Higher Education, 6(2), 129148.

Berg, B. L. (2001). Qualitative Research Methods for the Social Sciences. Boston: Allyn and Bacon.

Cabrera, N. L., \& Padilla, A. M. (2004). Entering and succeeding in the "culture of college": The story of two Mexican heritage students. Hispanic Journal of Behavioral Sciences, 26, 152-170.

Clements, E. (2000). Creating a campus climate in which diversity is truly valued. New Directions for Community Colleges, 28(4), 63-72.

Delgado Bernal, D. (2002). Critical Race Theory, Latino Critical Theory, and critical raced-gendered epistemologies: Recognizing students of color as holders and creators of knowledge. Qualitative Inquiry, 8(2), 105-126.

Fry, R. (2002). Latinos in higher education: Many enroll, too few graduate. Washington, DC: Pew Hispanic Center.

Gándara, P. (1995). Over the ivy walls: The educational mobility of low-income Chicanos. Albany: State University of New York Press.

Gandara, P., \& Contreras, F. (2009). The Latino education crisis: The consequences of failed social policies. Harvard University Press.

Gonzalez, N., Moll, L. C., \& Amanti, C. (2005). Funds of Knowledge: Theorizing Practices in Households, Communities, and Classrooms. Mahwah, New Jersey: Lawrence Erlbaum Associates, Publishers.

Hurtado, A. (2003). Voicing Chicana feminisms: Young women speak out on identity and sexuality. New York University Press. 
Hurtado, S., Milem, J. F., Clayton-Pedersen, A., \& Allen, W. R. (1998). Enhancing campus climates for racial/ethnic diversity: Educational policy and practice. Review of Higher Education, 21(3), 279-302.

Leon, D. (2003). Latinos in higher education. Oxford: Elsevier Science Ltd.

Llagas, C., \& Snyer, T. (2003). Status and trends in the education of Hispanics (NCES 2003-008). Washington, DC: National Center for Education Statistics.

Lopez, G. R., \& Vazquez, V. A. (2006). Parental involvement in Latino-impacted schools in the midwest: Recognizing the role and function of home-based knowledge and practices. Journal of School Public Relations, 27, 365-396.

Olivas, M. A. (1986). Latino college students. New York: Teachers College Press.

Orellana, M. F. (2003). In other words: Learning from bilingual kids' translating experiences. Evanston, IL: School of Education and Social Policy, Northwestern University.

Pascarella, E. T., \& Terenzini, P. T. (1979). Interaction effects in Spady's and Tinto's conceptual model of college dropout. Sociology of Education, 52, 197-210.

Pascarella, E. T., \& Terenzini, P. (1980). Predicting freshman persistence and voluntary dropout decisions from a theoretical model. Journal of Higher Education, 51, 60-75.

Quijada, P. D., \& Alvarez, L. (2006). Understanding the experiences of K-8 Latina/o students. In J. Castellanos, A. M. Gloria, \& M. Kamimura (Eds.), The Latina/o pathway to the Ph.D. (pp. 19-34). Sterling, VA: Stylus.

Rhoads, R. A. (1999). The politics of culture and identity: Contrasting images of multiculturalism and monoculturalism. In K. M. Shaw \& J. Valadez \& R. A. Rhoads (Eds.), Community colleges as cultural texts (pp. 103-124). Albany, NY: State University of New York Press.

Rodriguez, A. L., Guido-DiBrito, F., Torres, V., \& Talbot, D. (2000). Latina college students: issues and challenges for the $21^{\text {st }}$ century. NASA Journal, 37, 511-527.

Sanchez, B., Reyes, O., \& Singh, J. (2006). Makin' it in college: The value of significant individuals in the lives of Mexican American adolescents. Journal of Hispanic Higher Education, 5, 48-67.

Solórzano, D. G. (1998). Critical race theory, race and gender microaggressions, and the experience of Chicana and Chicano scholars. International Journal of Qualitative Studies in Education, 11, 121-136.

Spady, W. G. (1970). Dropouts from higher education: An interdisciplinary review and synthesis. Interchange, 1(1), 64-85.

Spradley, J. P. (1980). Participant observation. Fort Worth: Harcourt Brace College Publishers. 
St. John, E. P., Cabrera, A. F., Nora, A., \& Asker, E. H. (2002). Economic influences on persistence reconsidered: How can finance research inform the reconceptualization of persistence models? In J. M. Braxton (Ed.), Reworking the Student Departure Puzzle. Nashville: Vanderbilt University Press.

Stanton-Salazar, R., \& Dornbusch, S. M. (1995). Social capital and the social reproduction of inequality: The formation of informational networks among Mexican-origin high school students. Sociology of Education 68(2):116-35.

Suárez-Orozco, M. M., \& Páez, M. (2002). Latinos: Remaking America. Berkeley: University of California Press.

Tinto, V. (1987). Leaving college: Rethinking the causes and cures of student attrition. Chicago: University of Chicago Press.

Tinto, V. (1993). Leaving college: Rethinking the causes and cures of student attrition (2nd ed.). Chicago; London: University of Chicago Press.

Urrieta, L. (2009). Working from within: Chicana and Chicano activist educators in Whitestream schools. Tucson: The University of Arizona Press.

U.S. Census Bureau Fact Finder. (2005-2007). 2005-2007 American Community Survey 3-year estimates. Washington D.C: U.S. Department of Commerce. Retrieved May 3, 2009 from http://factfinder.census.gov/servlet/ACSSAFFFacts?_event=ChangeGeoC ontext\&geo_i=05000US32003\&_geoContext $=\&$ \&street $=\&$ \&county $=$ clark + county \&_cityTown $=$ clark + county $\& \_s t a t e=\& \_z i p=\& \_l a n g=e n \& \_s s e=$ on $\&$ ActiveGeoDiv $=\& \_u s e E V=\& p c t x t=f p h \& p s l=010 \& \_s u b m e n u I d=$ factsheet $1 \& d s \_n a m e=A C S \_2007 \_3 Y R \_S A F F \&$ _ci_nbr=null\&q_name=null\&reg= null\%3Anull\&_keyword=\&_industry=

Valenzuela, A. (1999). Subtractive schooling: U.S. -Mexican youth and the politics of caring. Albany: State University of New York Press.

Yosso, T. J. (2006). Critical race counterstories along the Chicana/Chicano educational pipeline. New York: Routledge Taylor \& Francis Group.

Zalaquett, C. P. (2005). Study of successful Latina/o students. Journal of Hispanic Higher Education, 5, 35-47. 